\title{
Assessment of heavy metal and physico-chemical pollution loadings of River Benue water at Makurdi using water quality index (WQI) and multivariate statistics
}

\author{
Raphael Terungwa Iwar $^{1}$ (D) . Joseph Terlumun Utsev² • Martina Hassan ${ }^{1}$
}

Received: 14 May 2020 / Accepted: 15 June 2021 / Published online: 25 June 2021

(c) The Author(s) 2021

\begin{abstract}
In this work, the quality of River Benue water at Makurdi was assessed for its heavy metal load alongside seven other physico-chemical parameters using water quality index (WQI) and multivariate statistical tools. A total of 45 samples from three (3) different points along the River course were collected for five months (October 2018-May, 2019) spanning the dry and wet seasons. Samples were analysed in accordance with standard methods. Most of the parameters evaluated were found to fall in the allowable limits of the World Health Organization (WHO) among others, except for colour, turbidity, total suspended solids, nickel, lead and cadmium. WQI analysis using the BISWQI, OWQI and CCMEWQI indicated that all indexing methods were suitable for estimating the WQI of River Benue as they all showed that the water corresponded to the classification as "poor water". Heavy metal index of the river ranged from13.40-6080.00 and from 47.07-7240.00 for the dry and wet seasons, respectively, and was majorly influenced by high cadmium and lead pollution levels. Principal component analysis (PCA) revealed three rotated factor with respective communality levels for both the dry and wet seasons. Factor 1 was positively loaded with nine parameters which accounted for $32.3 \%$ of the total variance during the dry season, while it was positively loaded with 10 parameters in the wet season accounting for $25.9 \%$ of total variance. Hierarchical cluster analysis (HCA) revealed that the river was zoned into four clusters each for both dry and wet seasons. Sampling points 2 and 3 were the most polluted during the dry season, while sampling point 1 was found to be the most polluted in the wet season. It was concluded that the increasing and diverse nature of anthropogenic activities on the river course was responsible for the deteriorating quality of the water. The study recommended continuous pollution monitoring and local regulations to reduce the entrance of both diffuse and point source pollution into the river.
\end{abstract}

Keywords Heavy Metal Index · River Benue $\cdot$ Water Quality Index · Multivariate Statistics · Pollution

\section{Introduction}

Water is a universal solvent and is one of the most commonly available natural resources of man which makes up about $70 \%$ of man's body (Talabi et al., 2020). Heavy metals on the other hand can be defined as "metals with densities that are five times heavier than water and are formed naturally from the terrestrial environments, and they are found

Joseph Terlumun Utsev

raphaeliwar@gmail.com

1 Department of Agricultural and Environmental Engineering, Federal University of Agriculture, Makurdi, Nigeria

2 Department of Civil Engineering, Federal University of Agriculture, Makurdi, Nigeria in rocks, plants, soils and sediments" (Talabi et al., 2020; Orobator et al., 2020).

The works of man and his industries have tendencies to increase the quantity of heavy metals in the environment, which favours environmental degradation (Ubwa et al., 2013). But high levels of heavy metals in water can be deleterious and injurious to man's health and his environment (Li et al., 2007). In Nigeria, the onset of river water pollution with respect to heavy metals $(\mathrm{Pb})$ was first reported by Monbreshola et al., (1983) in their studies on Nigerian rivers in Ibadan, South-West, Nigeria.

River Benue is one of the most important river, both in Benue State and Nigeria due to its location within the state capital city (Makurdi) and its favourable potentials for diverse beneficial purposes (recreation, agriculture, commerce and industry). In recent times, the River Benue has 
been subjected to tremendous changes in its quality as a result of increased human, industrial and commercial activities on the river banks (Akaahan et al., 2015; Eneji et al., 2017).

Over time, a few studies have been done to elucidate on the quality of River Benue water, moreover, as it traverses several communities and villages along its course. Eneji (2011) reported high concentrations of heavy metal in River Benue water around the Makurdi transect of the river. Their results indicated that the levels of trace contaminants in the water were above the maximum permissible levels allowed for drinking water as per the World Health Organization (WHO) standards. Similarly, Ejembi et al. (2018) carried out a bill of heavy metal loads in coastline deposits of River Benue and found out that heavy metal concentrations were above the allowable limits of WHO and NESREA. Deterioration in the features of water may be owed to the rapidly increasing urbanization trend, population pressure, industrial development, poor public health facilities and pollution of water assets by a diversity of dangerous substances and powerful pathogens (Ogedengbe and Akinbile, 2004).

These pollutions are mainly linked to raw anthropological and visceral litters, rubbish and manufacturing wastes. In Nigeria, the pollution of rivers in terms of heavy metals can be ascribed to indiscriminate release of raw effluents from industries, oxidization of steely provisions in buildings, leachates from waste dumps and automobiles, etc. (Jaji et al. 2007). According to FFTC (2008) as cited by Akinbile and Omoniyi (2018), raw human waste and junks are purposely and or unknowingly released into uncluttered channels, tributaries and rivers, leading to the contamination of freshwater reservoirs, watercourses and ponds. The panacea to such problems of environmental degradation remains frequent observations and supervision to preserve the quality features of the water and also the improvement of expertise for its handling and reuse (FFTC 2008).

According to Ogedengbe and Akinbile (2010), "In man's quest to increase his food supplies, obtain uncontaminated and clean water to drink and limit deterioration of his health and damage to his possessions, the products of his technological exploits that would have been used to his advantage have turned out to be the silent conqueror and threat to his existence".

The features of superficial and ground water assets can meaningfully alter water use in most parts of the world, particularly in the arid and semi-arid regions. In such areas where water contaminants from anthropological and manufacturing activities have extremely tainted the quality of water, it is advanced that the focus in water quality administration should be to periodically assess the contamination levels of aquatic bodies, regulate pollution sources and disseminate appropriate enlightenment campaigns (Akinbile and Omoniyi, 2018).
NBS (2009) posited that about $30 \%$ of Nigerians relied solely on rivers, tributaries, natural reservoirs and precipitation for their drinking water needs. They further projected that by the year 2030, many countries especially in Africa and Asia will face severe water scarcity as a result of climate change and generation of excessive wastewater from domestic, industrial and commercial undertakings.

Man, terrestrial animals/organisms, plants and waterbased creatures may be negatively influenced by reduced water quality which could be responsible for increased incidences of deaths, sicknesses, poor yields and retarded growths (Briace and De-Farrati, 2008). Thus, it has become imperative to constantly assess the water quality parameters of major sources (oceans, rivers, lakes, etc.) in order to maintain a balanced ecosystem and explore effective and sustainable management strategies for our water bodies (Yilmaz, 2007).

Water quality index (WQI), multivariate statistics and heavy metal index (HMI) have been utilized and found to be reliable tools for providing useful insights towards sustainable decision-making for water management. For instance, Rana et al. (2018), Sharma et al. (2020), Vasistha and Ganguly (2020), Kondom et al. (2021) have demonstrated in their various studies that the foregoing approaches are suitable tools for assessing water pollution status of rivers, groundwater and leachate in different climes.

The obligation of frequent water quality monitoring must not be overemphasized. It is vital and supreme if public health and major water resources must be preserved in Nigeria and elsewhere. Therefore, the focus of the current research was to assess the quality of River Benue water at Makurdi with emphasis on heavy metals contamination which was elucidated using the HMI and the contributions of each heavy metal to the river pollution load during the wet and dry seasons. Furthermore, the instantaneous pollution status of the river was comparatively assessed using the BIS 10500 WQI (BISWQI), the Oregon WQI (OWQI) and the Canadian Council of Ministers of the Environment WQI (CCMEWQI) approaches. Similarly, principal component analysis (PCA) and hierarchical cluster analysis (HCA) were used to understand the interrelationships among the pollutants and also to infer pollution sources in the river.

The foregoing is important if proper harnessing and utilization of water from the river for various purposes (home, manufacturing and farming) so as to upsurge fibre and food production in the area are to be achieved.

Most importantly, it has been recently observed that diverse land use practices and anthropogenic impacts (sand mining, industrial effluent discharge, irrigation and herbicides application, flooding, indiscriminate solid waste dumping, etc.) have been associated with the river in the study location, thus increasing suspicion of its increased pollution loads, especially with regards to toxic, non-biodegradable 
and carcinogenic pollutants such as heavy metals and herbicides (Eneji et al., 2011).

Therefore, since most of the communities situated along the course of the river depend heavily on it for their day to day portable, recreational and agricultural needs, it is pertinent to ascertain the level of pollution of the river and recommend the right purification and management measures to be adopted.

The thrust of the study was thus to assess the pollution levels of River Benue water at Makurdi at three selected locations along the river course. These locations are associated with various anthropogenic impacts and may be a reason for great variations in the quality of the water at the different points.

\section{Materials and methods}

\section{The area of study}

The study area in the current work was River Benue located in Makurdi town (capital city of Benue state-Nigeria). Its earthly coordinates are $8^{\circ} 210$ North, $8^{\circ} 300$ East. This river flows and passes through different locations and villages in the town. It is one of the two main rivers in Nigeria. Its origin is traced to the Cameroonian mountains as it traverses westwards through Makurdi to meet the other major river (River Niger) at Lokoja in Kogi State. Some of its tributaries are Rivers Katsina-Ala, Donga, Mu, Bantaji and Taraba among others. Around the New Bridge area in Makurdi, the river has an average depth and cross-sectional area of $7.82 \mathrm{~m}$ and $4608.42 \mathrm{~m}^{2}$, respectively, with an average width of $1.194 \mathrm{~km}$. The basin of the river which is concealed with meta-sediments is made up of land area below $300 \mathrm{~m}$ above sea level. The overflow plain dominated with large spans of swamps is ideal for irrigation-based dry spell cultivation. The river is a known and utilized source of natural water, alluvial and sand deposits in commercial quantities to the environs. Benue Roof Tiles Company Ltd., the building and brick-making industries are the major beneficiaries of these natural endowments. The river is used for agricultural, commercial, industrial, recreational and domestic purposes, e.g. fishing, washing of plates, drinking and abattoir (meat market) with uncontrolled waste disposal on the river banks and course. The people around this river locations deposit a lot of their waste products into the river or immediate environs. It is therefore important that these sources be analysed in order to elucidate on the quality of the water at these locations.

Makurdi lies between latitude $7.733^{\circ} \mathrm{N}$ and longitude $8.5391^{\circ} \mathrm{E}$ of Greenwich meridian as shown in Fig. 3. It is located in the Southern guinea savanna area of Nigeria and consists of two different (dry and wet) seasons. The highest rainfalls in the area are annually experienced between the months of April and October with a mean value of $1137 \mathrm{~mm}$ (Isikwue and Onyilo, 2010).

In 2007, Makurdi population was estimated at 500,797 people (The World Gazetteer, 2013). The topographic map of the area shows that the land form is slightly irregular. Most parts of the land have been deprived of its original land cover comprising mostly of tall trees, tall grasses and shrubs. The yearly potential evapotranspiration is pegged at about $2602 \mathrm{~mm}$, with mean yearly relative humidity of about 40.7\% (Isikwue and Onyilo, 2010).

Average monthly temperature of the area falls within $17-36{ }^{\circ} \mathrm{C}$. The high temperatures experienced in Makurdi are credited chiefly to the proximity of the town to the River Benue as a result of the reflection of solar radiation from the river back to its environs. Figure 1 is the map of the town displaying the River Benue and its tributaries.

\section{Sampling and analytical procedures}

Three (3) sampling points were chosen along the course of the river (Fig. 2). Samples were collected by the grab method in triplicate at each sampling point for a period of five months encompassing both the dry and wet periods. Specifically, a total of 45 samples were collected between the months of October, 2018, and May, 2019.

Some of the anthropogenic activities observed at the selected sampling points along the river course included indiscriminate municipal solid and liquid waste releases and large-scale fishing (Sampling point 2), small-scale farming, laundry and large-scale fishing and recreation (Sampling point 1) and effluent discharge, abattoir, fishing,

sand mining, ferrying, recreation and municipal solid waste disposal (sampling point 3 ). Detailed narrative of the sampling settings is given in Table 1. Preservation of samples and analysis was done at the Chemistry laboratory of the Benue State University following the standard methods (APHA, 2005; CPCB, 2007). The concentration of twelve (12) physico-chemical parameters in the water samples was measured viz. colour, temperature, turbidity, total dissolved solids (TDS), $\mathrm{pH}$, electrical conductivity (EC), total suspended solids (TSS), lead ( $\mathrm{Pb})$, zinc ( $\mathrm{Zn})$, cadmium $(\mathrm{Cd})$, copper $(\mathrm{Cu})$ and nickel $(\mathrm{Ni})$ using standard laboratory procedures and equipment (APHA, 2015; Radojovic and Bashkin, 1999).

Temperature was determined in situ with a mercury thermometer, $\mathrm{pH}$ was measured using a digital $\mathrm{pH}$ meter, colour was determined using a portable data logging spectrophotometer (HACH DR 2010 equipment), TDS was determined by a HM Digital TDS-4 pocket size meter, EC was determined with the aid of a Suntex SC-120 conductivity meter,

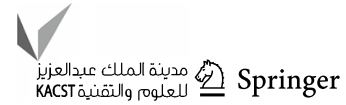




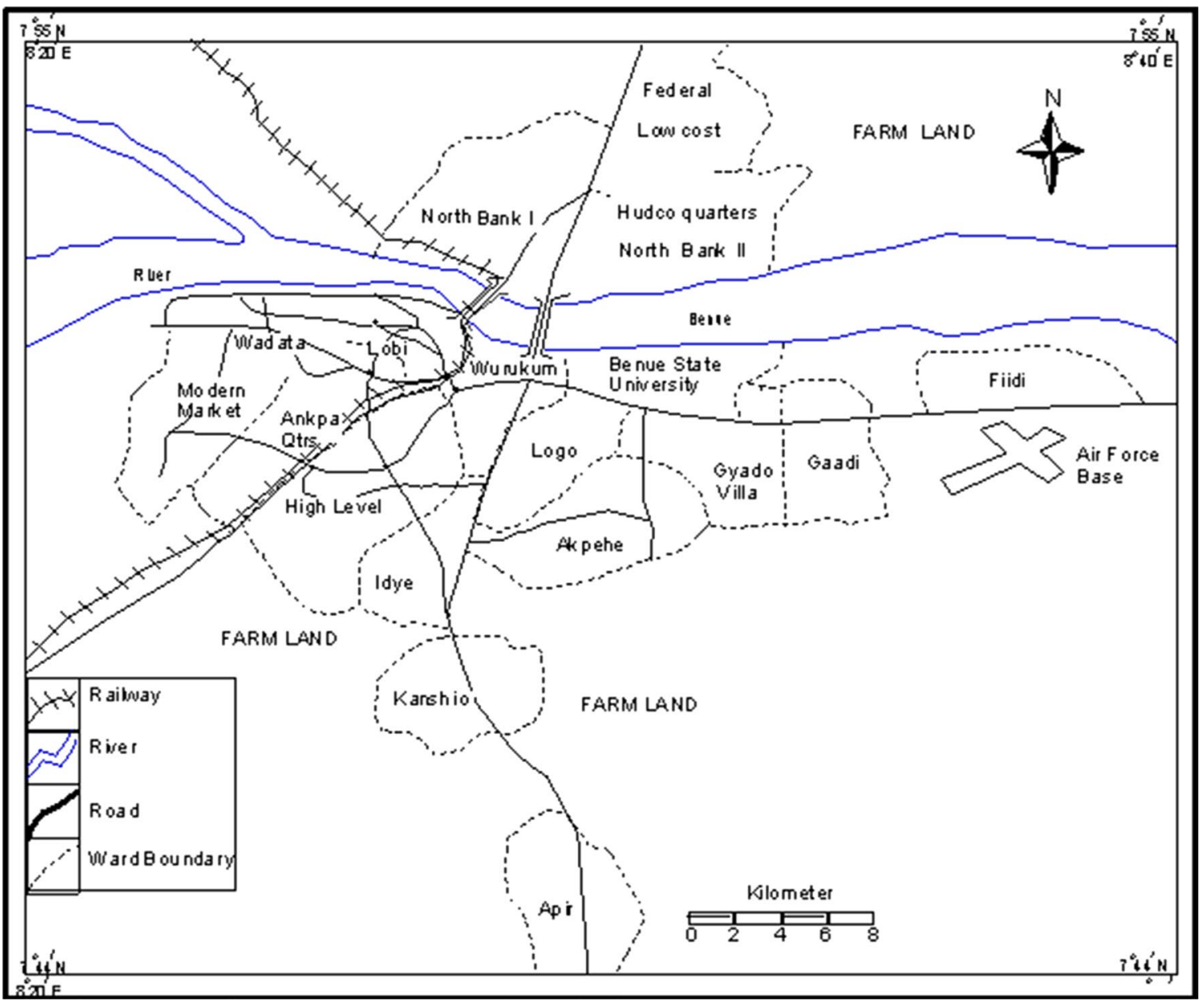

Fig. 1 Map of Makurdi town revealing the River Benue and its tributaries Source Benue State Ministry for Lands and Survey, (2011)

turbidity was determined using a HACH 2100P turbidity meter.

TSS was determined using a HACH DR 2010 TSS meter. The presence of $\mathrm{Cu}, \mathrm{Pb}, \mathrm{Zn}, \mathrm{Cd}$ and $\mathrm{Ni}$ was determined by the methods described by Akinbile et al., (2013) using an atomic absorption spectrophotometer (PG 990 AAS).

\section{Descriptive statistics, spatio-temporal variations and water quality index}

Descriptive statistics such as minimum, maximum, mean, standard deviation, skewness and kurtosis for all water quality parameters studied at the chosen locations and times were done using the Statistical Package for Social Sciences (SPSS) software, version 21. Furthermore, the spatio-temporal variations in the water quality were expressed in graphical illustrations using the Microsoft Excel package Version 10.

Upon obtaining the essential physico-chemical features of the water samples, the quality index was evaluated with the use of WQI tool. WQI was used for approximating the level of pollution of the river by showing the combined consequences of the physico-chemical features at a glance. It is a simplified way of expressing the extent of pollution or otherwise of a water body irrespective of the huge number of variables involved. It gives information about the quality class of the water at a glance.

WQI calculations for the current study were determined based on the BIS 10500 WQI (BISWQI) with slight modifications in which the Nigerian Standard for Drinking Water Quality (NSDWQ) was used as the maximum permissible limit for each parameter. BISWQI determination involved three successive steps. "The first step was 'assigning weights'. Each of the 12 parameters was assigned a weight (wi), according to its relative importance in the overall drinking water quality analysis. The most significant parameters were given a weight of 5 and the least significant a weight of 1" (Al-Omran et al., 2015). Currently, the highest weight of ' 5 ' was allocated to $\mathrm{Cd}$, while $\mathrm{Ni}, \mathrm{Pb}, \mathrm{Zn}, \mathrm{Cu}$ and TDS were given a weight of ' 4 ' each. The less harmful 


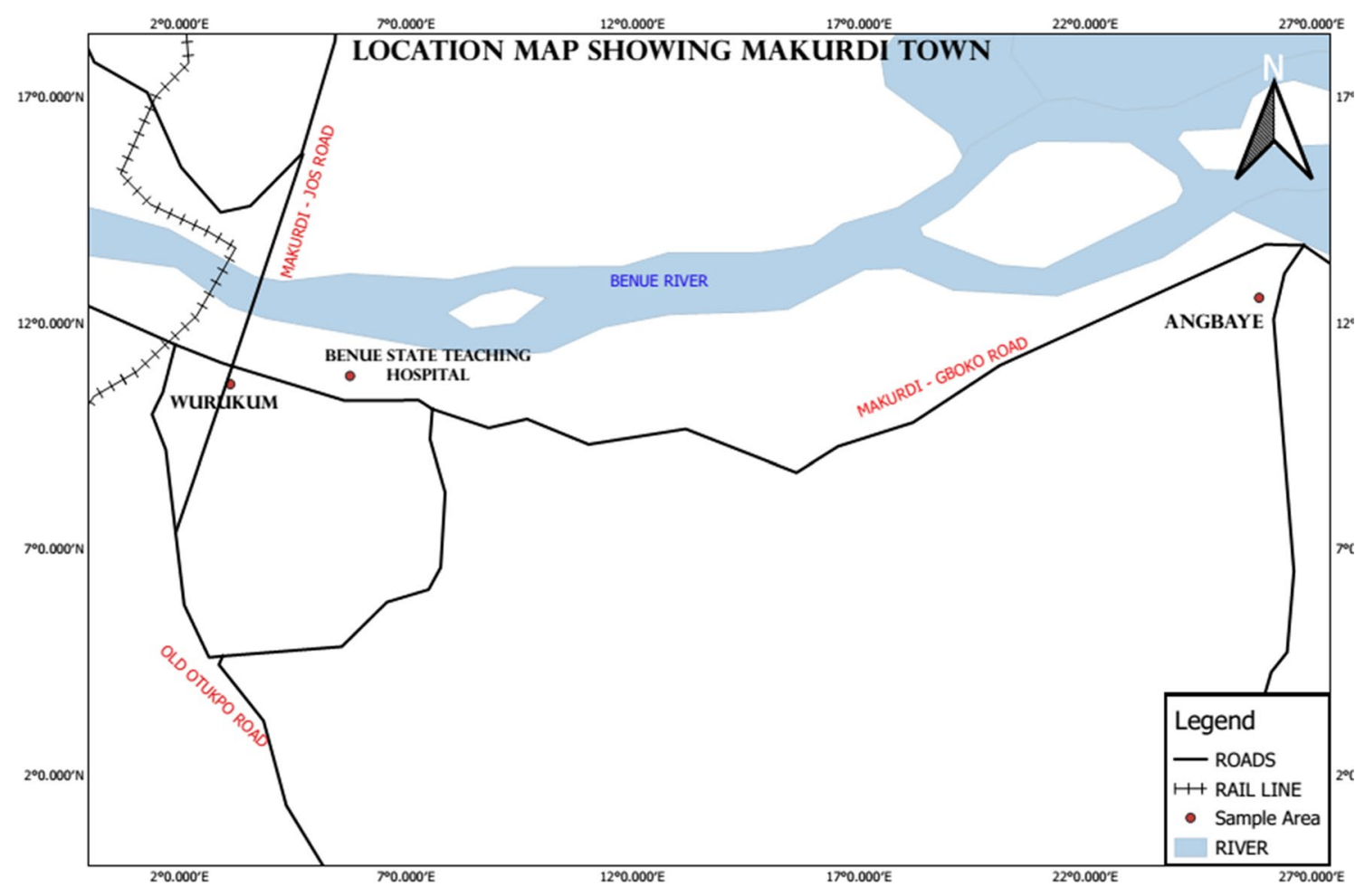

Fig. 2 Map of Makurdi showing River Benue and the sampling points

Table 1 Location of sampling points

\begin{tabular}{|c|c|c|c|c|}
\hline Sampling station & Description & Land use and anthropogenic activities & Latitude & Longitude \\
\hline ST 1 & Angbaye & Crop production, brick laying, recreation, fishing, and hunting & $7^{\circ} \mathrm{N} 73^{\prime} 28^{\prime \prime}$ & $8^{\circ}$ E $54^{\prime} 79^{\prime \prime}$ \\
\hline ST2 & Brewery/BSUTH & $\begin{array}{l}\text { Crop production, commercial activities brick laying, fishing, industrial efflu- } \\
\text { ent discharge and solid waste dumping }\end{array}$ & $7^{\circ} \mathrm{N} 72^{\prime} 55^{\prime \prime}$ & $8^{\circ}$ E $57^{\prime} 47^{\prime \prime}$ \\
\hline ST3 & Wurukum Abattoir & $\begin{array}{l}\text { Mild crop production, commercial activities (Wurukum Market, Abbattoir), } \\
\text { sand mining, fishing, solid waste dumping, ferrying and recreation }\end{array}$ & $7^{\circ} \mathrm{N} 73^{\prime} 78^{\prime \prime}$ & $8^{\circ}$ E $70^{\prime} 22^{\prime \prime}$ \\
\hline
\end{tabular}

parameters (temperature, $\mathrm{pH}$, turbidity, TSS, electrical conductivity and colour) were given a value of ' 3 ' each.

The next step was the 'relative weight calculation'. "The relative weight $\left(\mathrm{W}_{\mathrm{i}}\right)$ was computed using Eq. 1

$W_{i}=\frac{w_{i}}{\sum_{i=1}^{n} w_{i}}$

where $W_{i}$ is the relative weight $w_{i}$ is the weight of each parameter and $\mathrm{n}$ is the number of parameters" ((Al-Omran et al., 2015).

"The third step is 'quality rating scale calculation'. The quality rating scale $\left(\mathrm{q}_{\mathrm{i}}\right)$ for each parameter is calculated using Eq. 2.

$q_{i}=\frac{C_{i}}{S_{i}} \times 100$ where $\mathrm{q}_{\mathrm{i}}$ is the quality rating, $\mathrm{C}_{\mathrm{i}}$ is the concentration of each chemical parameter in each water sample in $\mathrm{mg} / \mathrm{L}$, except Temperature, $\mathrm{pH}$, electrical conductivity and turbidity, while $\mathrm{S}_{\mathrm{i}}$ is the WHO (2011) standard for each chemical parameter.

Finally, the $\mathrm{W}_{\mathrm{i}}$ and $\mathrm{q}_{\mathrm{i}}$ were used to calculate the $\mathrm{SI}_{\mathrm{i}}$ for each chemical parameter (Eq. 3), and then the BISWQI is calculated using Eq. 4.

$\mathrm{SI}_{i}=W_{i} \times q_{i}$

$\mathrm{BISWQI}=\sum_{i=1}^{n} \mathrm{SI}_{i}$

where $\mathrm{SI}_{\mathrm{i}}$ is the sub-index of each parameter, $\mathrm{q}_{\mathrm{i}}$ is the rating based on concentration of each parameter and $n$ is the number of parameters" (Al-Omran et al., 2015). The computed WQI values were then classified into five categories 
(Table 4) in accordance with the methods of Rana et al. (2018), Asit and Surajit (2015), Al-Omran et al. (2015), Ramakrishnalah et al. (2009); Hameed (2012) and KetataRokbani et al. (2011). A general BISWQI was computed for the river water based on the grand means of chemical parameters considered in comparison with the OWQI and CCMEWQI which are well-known standard WQI classification methods (Rana et al., 2018). This was done to enable the authors to draw a holistic conclusion on the quality of the River Benue water in the two seasons.

The OWQI and CCMEWQI are computed using Eqs. 5-6, respectively, Calmuc et al. (2018); Rana et al. (2018).

$\mathrm{OWQI}=\sqrt{\frac{n}{\sum_{i=1}^{n} \frac{1}{S_{i}^{2}}}}$

where $n$ is the number of parameters, $S_{i}$ is the sub-index of the sub-index ith parameter.

CCMEWQI $=100-\left(\frac{\sqrt{F_{1}^{2}+F_{2}^{2}+F_{3}^{2}}}{1.732}\right)$

where

$F_{1}=\left(\frac{\text { Number of variables whose objectives are not met }}{\text { Total number of variables }}\right) \times 100$

$F_{2}=\left(\frac{\text { Number of tests whose objectives are not met }}{\text { Total number of tests }}\right) \times 100$

$\mathrm{F}_{3}=$ Amplitude - the range to which the failed tests are above the guidelines

According to Fatai (2011) as cited by Akinbile and Omoniyi (2018) "principal component analysis (PCA) otherwise called factor analysis is based on a varimax rotation technique from Statistical Package for the Social Sciences (SPSS Version 15.0) which is used to investigate whether a number of variables of interest $Y_{1}, Y_{2}, Y_{3} \ldots, Y_{i}$, are linearly related to a smaller number of unobservable factors $F_{1}, F_{2}, F_{3} \ldots F_{k}$. It is assumed that each $Y$ variable is linearly related to two factors, according to Sharma (1996) as follows (Eqs. 7-9):

$Y_{1}=\beta_{10}+\beta_{11} F_{1}+\beta_{12} F_{2}+\beta_{13} F_{2}+e_{1}$

$Y_{2}=\beta_{20}+\beta_{21} F_{1}+\beta_{22} F_{2}+\beta_{23} F_{2}+e_{2}$,

$Y_{3}=\beta_{30}+\beta_{31} F_{1}+\beta_{32} F_{2}+\beta_{33} F_{2}+e_{3}$.

The error terms $e_{1}, e_{2}$ and $e_{3}$, indicate that the hypothesized relationships are not exact. In the special vocabulary of factor analysis, the parameter $\beta_{i j}$ represents the loadings. For

\section{Determination of heavy metal index (HMI)}

The HMI in this study was estimated following the procedure outlined by Zakhem and Hafez (2015) and utilized again by Sharma et al. (2020). HMI was used to rate the combined influence of different heavy metals on the integral quality of water. Usually, weights between 0 and 1 are assigned to the individual heavy metals depending on the relative importance of the metals. The techniques for determination of HMI are well documented in Zakhem and Hafez (2015) and were adopted for use in this study with slight modifications based on the NSDWQ. The mean value of each heavy metal was used for calculating the HMI for the two seasons (dry and wet). HMI below 19 was taken as low, those from example, $\beta_{12}$ is called the loading of variable $Y_{1}$ on factor $F_{2}$. Each observation variable is a linear function of independent factors and error terms and can be written as in Eq. 10:

$Y_{i}=\beta_{i 0}+\beta_{i 1} F_{1}+\beta_{i 2} F_{2}+(1) e_{i}$.

This can be written in terms of variance as in Eqs. 11 and 12:

$$
\begin{aligned}
\operatorname{Var}\left(Y_{i}\right) & =\beta_{i 1}^{2} \operatorname{Var}\left(F_{1}\right)+\beta_{i 2}^{2} \operatorname{Var}\left(F_{2}\right)+\beta_{i 3}^{2} \operatorname{Var}\left(F_{3}\right)+(1)^{2} \operatorname{Var}\left(e_{i}\right) \\
& =\beta_{i 1}^{2}+\beta_{i 2}^{2}+\beta_{i 3}^{2}+\sigma_{i}^{2}, \\
\operatorname{Var}\left(Y_{i}\right) & =\beta_{i 1}^{2}+\beta_{i 2}^{2}+\beta_{i 3}^{2}+\sigma_{i}^{2},
\end{aligned}
$$


where $\beta_{i 1}^{2}+\beta_{i 2}^{2}+\beta_{i 3}^{2}=$ communality, and $\sigma_{i}^{2}=$ specific variance. From Eq. 6, the variance of $Y_{i}$ has three parts: first, the communality of the variable is the part that is explained by the common factors $F_{1}, F_{2}$ and $F_{3}$. Second, the specific variance is the part of the variance of $Y_{i}$ that is not accounted for by the common factors. If the three factors were perfect predictors of the variables, then Eq. 13 suffices as follows:

$e_{i}=e_{2}=e_{3}=0$ always, and $\sigma_{i 1}^{2}=\sigma_{i 2}^{2}=\sigma_{i 3}^{2}=\sigma 3_{i}^{2}=0$.

After identifying the major hidden pollutant sources in the water samples, the next step was to examine the similarity among considered stations for possible zonings according to the level of existing pollution. For this purpose, the hierarchical cluster analysis (HCA) was used to decide which of the sampling points (stations) are most similar to each other, considering all of the pollution properties simultaneously. HCA employs the familiar concept of distance, considering two points, I and j, with coordinates $\left(X_{1 i} ; X_{2 i} ; X_{3 i}\right)$ and $\left(X_{1 j} ; X_{2 j} ; X_{3 j}\right)$, respectively; the Euclidian distance between the two points is hypotenuse of the triangle ABC expressed as in Eq. 14".

\section{Results and discussion}

\section{Descriptive statistics and spatio-temporal variation in River Benue water quality}

\section{Physical parameters}

Results of descriptive statistics revealing the quality features of the Benue River during the dry and wet spells considering the spatial difference of the sampling stations as compared with the World Health Organization (WHO 2015), standards for drinking water, the Food and Agricultural Organization (FAO 2015) standards and the Nigerian Standards for Drinking Water Quality (NSDWQ 2015) are as shown in Table 2.

From Table 2, it was observed that the colour varied from 95 to 250 pt.co and from 160 to 425 pt.co with mean values of $172.5 \pm 50.848$ and $292.5 \pm 146.856$ for the dry and wet seasons, correspondingly. The slim variance noticed in the colour of the water in the two seasons may be as a result of the point that colour tends to change in wet season due to rain drops, which disturbs bottom sediments that rise and

$\mathrm{D}(\mathrm{I}, \mathrm{j})=\left(A^{2}+B^{2}+C^{2}\right)^{1 / 2}=\left\{\left(X_{1 i}-X_{1 j}\right)^{2}+\left(X_{2 i}-X_{2 j}\right)^{2}+\left(X_{3 i}-X_{3 j}\right)\right\}^{1 / 2}$.

These methods have been previously used by other researchers to elucidate on features of surface water resources in several regions of the world (Rana et al., 2018; Akinbile and Omoniyi, 2018; Al-Omran et al., 2015; Park et al., 2014). dissolve in the water. Colour concentrations in the water were far above the NSDWQ value of 15 for drinking water quality.

The results for temperature as obtained changed from 22 to $30.7^{\circ} \mathrm{C}$ and from 26 to $30.1^{\circ} \mathrm{C}$ with mean values of 26.35 $\pm 3.077^{\circ} \mathrm{C}$ and $28.05 \pm 1.633^{\circ} \mathrm{C}$ for the dry and wet seasons accordingly.

Table 2 Descriptive statistics of physico-chemical parameters of River Benue water

\begin{tabular}{|c|c|c|c|c|c|c|c|c|c|c|}
\hline \multirow{2}{*}{$\begin{array}{l}\mathrm{N}=3 \\
\text { Parameters }\end{array}$} & \multicolumn{3}{|c|}{ Dry season } & \multicolumn{3}{|c|}{ Wet season } & \multicolumn{3}{|l|}{ Standards } & \multirow[t]{2}{*}{ Remark } \\
\hline & Min & Max & Mean \pm SD & Min & Max & Mean \pm SD & WHO & FAO & NSDWQ & \\
\hline TDS (mg/l) & 125 & 570 & $347.5 \pm 173.012$ & 150 & 600 & $375 \pm 158.745$ & 1000 & 2000 & 500 & $* *$ \\
\hline $\mathrm{EC}(\mu S / \mathrm{cm})$ & 50 & 304 & $177 \pm 128.051$ & 19 & 315 & $167 \pm 92.791$ & 4000 & 3000 & 5000 & $* *$ \\
\hline Temp $\left(C^{0}\right)$ & 22 & 30.7 & $26.35 \pm 3.077$ & 26 & 30.1 & $28.05 \pm 1.633$ & 30 & 25 & 30 & $*$ \\
\hline $\mathrm{pH}$ & 7.8 & 8.7 & $8.25 \pm 0.267$ & 7.0 & 8.4 & $7.7 \pm 0.133$ & $6.50-8.50$ & $6.50-8.50$ & $6.50-8.50$ & $*$ \\
\hline TSS (mg/l) & 33 & 377 & $205 \pm 111.891$ & 37 & 385 & $211 \pm 133.164$ & - & - & 0.100 & $* * *$ \\
\hline Colour (pt.co) & 95 & 250 & $172.5 \pm 50.848$ & 160 & 425 & $292.5 \pm 46.856$ & - & - & 15 & $* * *$ \\
\hline Turbidity (NTU) & 20 & 531 & $275.5 \pm 158.602$ & 30.1 & 455 & $242.55 \pm 163.110$ & 1.5 & 35.0 & 5 & $* * *$ \\
\hline Lead (mg/l) & 0.025 & 0.592 & $0.309 \pm 0.171$ & 0.141 & 0.592 & $0.367 \pm 57.381$ & 0.01 & 0.01 & 0.01 & $* * *$ \\
\hline Zinc (mg/l) & 0.097 & 3.628 & $1.863 \pm 1.445$ & 0.595 & 0.993 & $0.794 \pm 0.302$ & 5 & 5 & 3 & $* *$ \\
\hline Copper (mg/l) & 0 & 1.134 & $0.567 \pm 0.370$ & 0 & 0 & $0 \pm 0.017$ & 2 & 2 & 1 & $* *$ \\
\hline Cadmium (mg/l) & 0.058 & 0.199 & $0.129 \pm 0.400$ & 0 & 0.150 & $0.075 \pm 0.072$ & 0.003 & 0.003 & 0.003 & $* * *$ \\
\hline Nickel (mg/l) & 0 & 0 & $0 \pm 0.144$ & 0.201 & 0.232 & $0.217 \pm 0.012$ & 0.07 & 0.02 & 0.02 & $* * *$ \\
\hline
\end{tabular}

${ }^{*}$ Within limits

*** Below limits

**** Above limits 
The observed differences in temperature for the two spells can be ascribed to the point that temperature tends to be higher in the dry spell as reported by NIMET (2009). The dry spell had the mean temperature of $26.35 \pm 3.077{ }^{\circ} \mathrm{C}$, while the wet spell had a mean value of $28.05 \pm 1.633^{\circ} \mathrm{C}$ (Table 1). This could be ascribed to weather changes caused by the uniqueness of the two main spells in Nigeria. Except for the FAO value of $25^{\circ} \mathrm{C}$, the average temperatures in the study area were within the acceptable limits of WHO and NSDWQ Fig. 3. These findings are in close alignment with those of Igbinosa et al. (2012).

Turbidity varied from 20 to 531 NTU during the dry spell and from 30.1 to 455 NTU in the wet spell with average values of $275.5 \pm 158.602$ and $242.55 \pm 163.110$, respectively, for the dry and wet spells which were in tandem with the observations of Eloskkay and Abukila (2014). Mean values of turbidity were higher than the WHO, FAO and NSDWQ Standards for drinking water (Table 2) (Figs. 3,4,5). Advanced figures recorded for turbidity all through the wet spell in the current study may be associated with the surge in water level ensuing from amplified rainfall amounts, improved soil removal rates and increased carriage of separated soil units. Also, at this level, aquatic resources may give away their capabilities to aid in the abundance of water-based ecosystems, as the most apparent consequence is a decrease in the light offered for photosynthesis. The foregoing phenomenon tends to diminish the aquatic plant development rates and in turn restricts the quantity of waterbased creatures that nourish on these floras and lastly fish population that depend on water-based creatures for their nourishment are affected.

Total dissolved solid (TDS) varied from 125 to $570 \mathrm{mg} / \mathrm{L}$ with average figures of $347.5 \pm 173.012 \mathrm{mg} / \mathrm{L}$ for the dry season and also varied from 150 to $600 \mathrm{mg} / \mathrm{L}$ during the wet spell with an average worth of $375 \pm 158.745 \mathrm{mg} / \mathrm{L}$. For both spells, TDS values were found to be lower than the WHO limit of $1000 \mathrm{mg} / \mathrm{L}$ (WHO 2010), the FAO limit of $2000 \mathrm{mg} / \mathrm{L}$ but higher than the NSDWQ limit of $500 \mathrm{mg} / \mathrm{L}$ for drinking water. The findings of this work are closely aligned to those of Raman et al. (2009).

Total suspended solids (TSS) varied from 33 to $377 \mathrm{mg} / \mathrm{L}$ during the dry spell with an average of $205 \pm 111.891 \mathrm{mg} / \mathrm{L}$ and from 37 to $385 \mathrm{mg} / \mathrm{L}$ during the wet spell with an average of $211 \pm 133.164 \mathrm{mg} / \mathrm{L}$. These figures were found to be higher than the NSDWQ allowable limits for drinking water. This can be attributed to the presence in high concentrations of animal matter, industrial waste, decaying plant and sewage in most of the studied locations. High concentrations of suspended solids can cause many problems for streams,
Fig. 3 Spatio-temporal variation in temperature, $\mathrm{pH}$, lead and turbidity
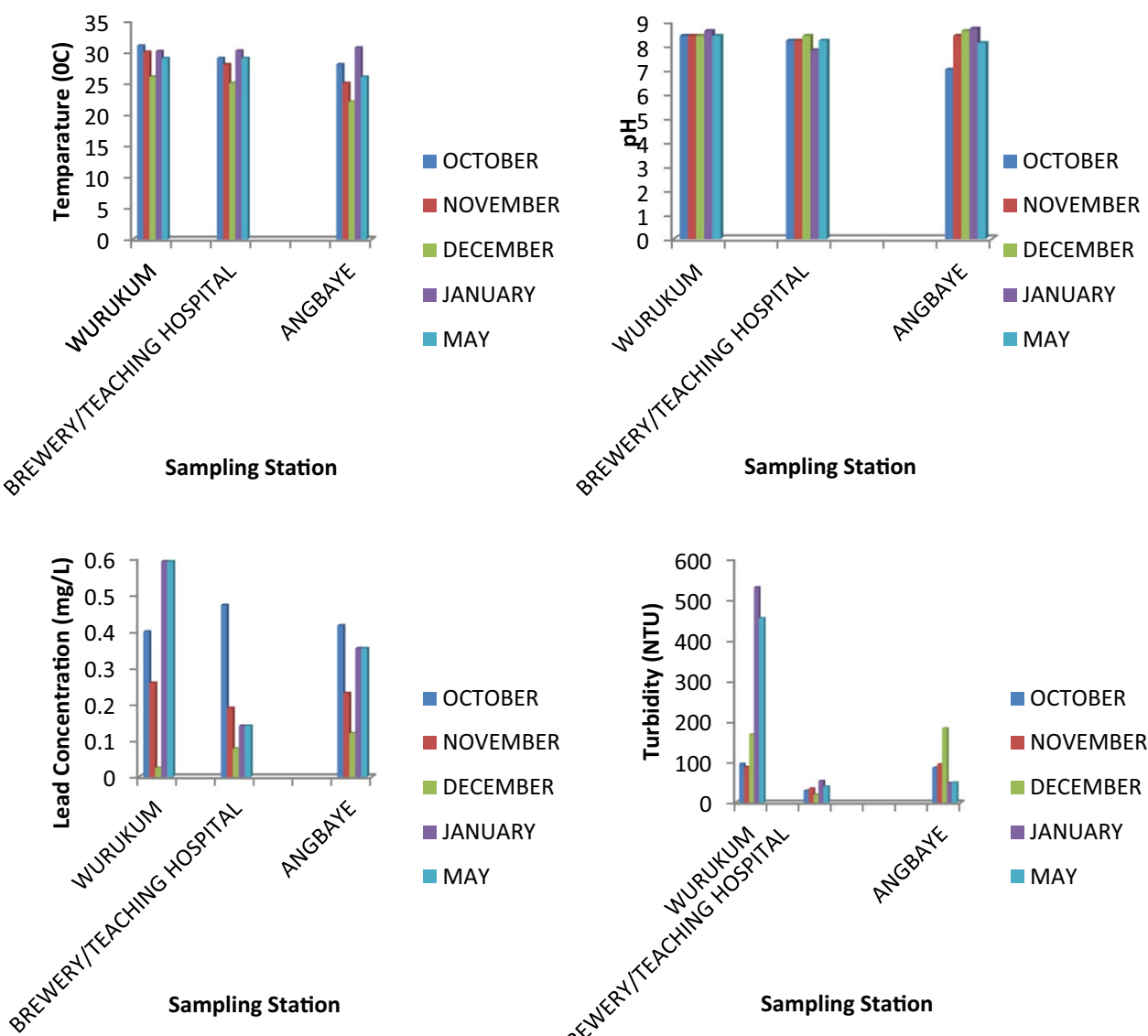

- OCTOBER

- NOVEMBER

DECEMBER

JANUARY

MAY

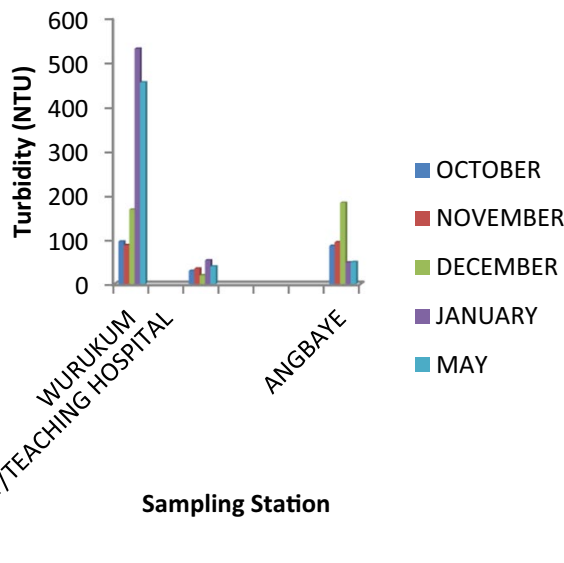


Fig. 4 Spatio-temporal variation in cadmium, nickel, TDS and electrical conductivity
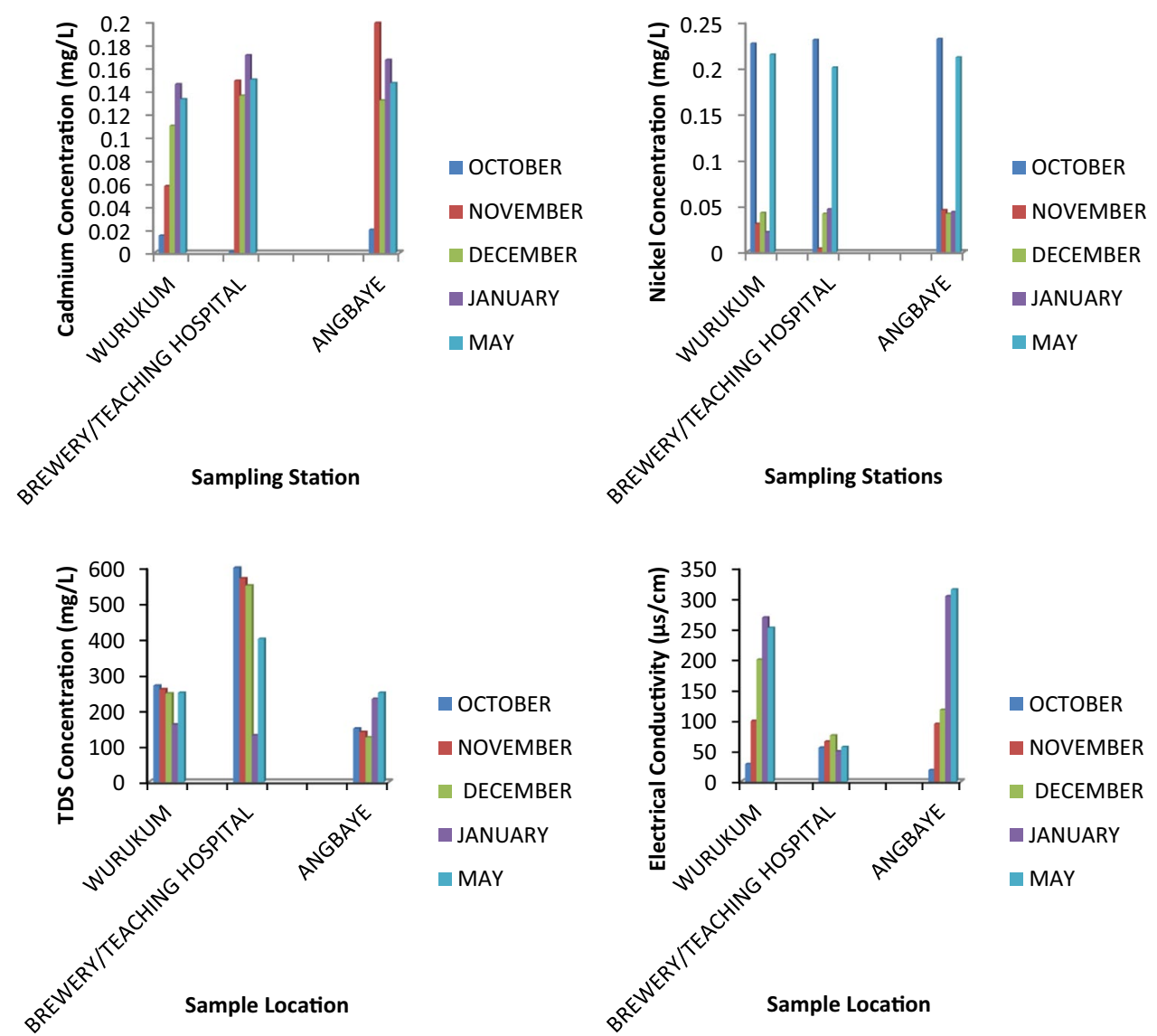

OCTOBER
NOVEMBER

- DECEMBER

- JANUARY

- MAY

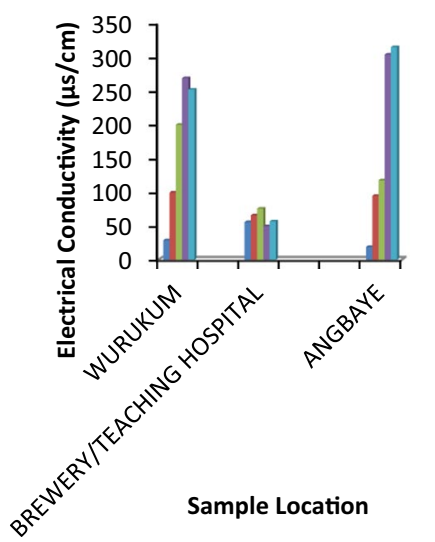

- JANUARY

MAY rivers and aquatic life; a similar trend was reported by Anwar et al. (2011).

\section{Chemical parameters}

The $\mathrm{pH}$ of River Benue water showed relative variations (7.8-8.7) with an average of $8.25 \pm 0.267$ during the dry spell. It may be infered that the water was slightly alkaline and might be unwholesome for portable uses during this period. Conversely, the $\mathrm{pH}$ values during the wet spell ranged from $7.0-8.4$ with an average of $7.7 \pm 0.133$. This is attributable to the numerous anthropogenic engagements along the course of the river during the year. These figures were observed to fall within the acceptable limits for drinking water (Figs. 3,4,5). Charkhabi and Sakizadeh (2006) also reported a similar trend for $\mathrm{pH}$ in their study on water quality changes in the most polluted reach of the Anzali wetland in northern Iran.

Electrical conductivity (EC) varied from 50 to $304 \mu \mathrm{S} / \mathrm{cm}$ with an average of $177 \pm 128.051 \mu \mathrm{S} / \mathrm{cm}$ during the dry period and from 19 to $315 \mu \mathrm{S} / \mathrm{cm}$ during the wet period with an average of $167 \pm 92.791 \mu \mathrm{S} / \mathrm{cm}$. Average figures for conductivity were found to fall below the WHO, FAO and NSDWQ standard value. The low level of EC during the wet spell may be as a result of the increased volume of the river and decreased temperature in such seasons which does not favour speciation that tend to alter or increase conductivity in water (Chikogo et., al 2012).

\section{Spatio-Temporal variations in heavy metals in River Benue}

Heavy metal like $\mathrm{Pb}, \mathrm{Zn}, \mathrm{Cu}, \mathrm{Cd}$ and $\mathrm{Ni}$ were tested and detected in the water samples during both (dry and wet) seasons (Table 2). Copper $(\mathrm{Cu})$ and nickel $(\mathrm{Ni})$ were not detected at some time during the dry and wet seasons (Table 2). Presence of lead, zinc, copper, cadmium and nickel varied from 0.025 to $0.592,0.097$ to $3.628,0$ to $1.134,0.058$ to $0.199,0$ to $0 \mathrm{mg} / \mathrm{L}$, with averages of $0.309 \pm 0.171,1.863 \pm 1.445,0.568 \pm 0.370,0.129 \pm 0.400$ and $0 \pm 0.144 \mathrm{mg} / \mathrm{L}$, respectively, in dry season. Similarly, they were found to vary from 0.141 to $0.592,0.595$ to $0.099,0$ to 0,0 to 0.150 and 0.201 to $0.232 \mathrm{mg} / \mathrm{L}$ with 
Fig. 5 Spatio-temporal variations in colour, TSS, copper and zinc

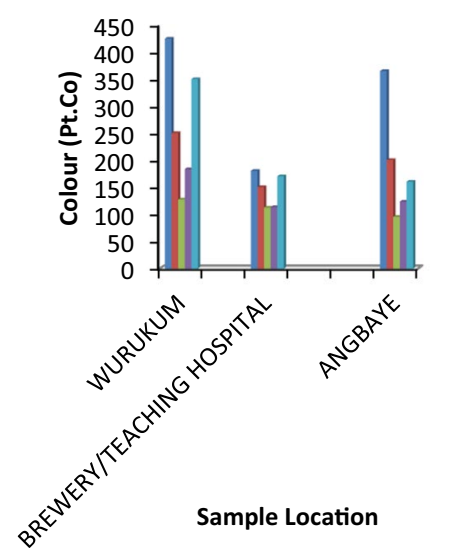

- OCTOBER

- NOVEMBER

- DECEMBER

- JANUARY

MAY

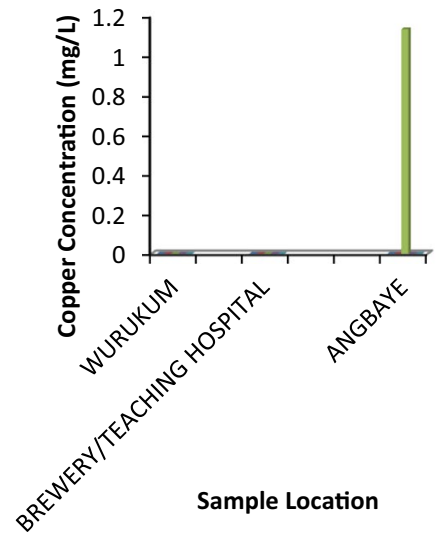

OCTOBER

- JANUARY

- MAY

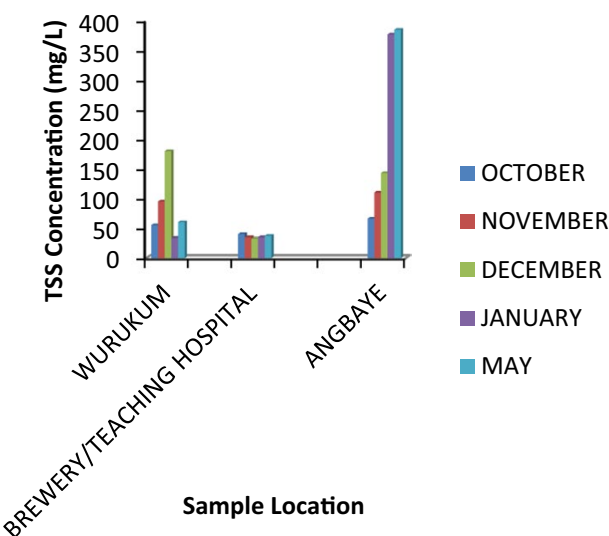

NOVEMBER

DECEMBER

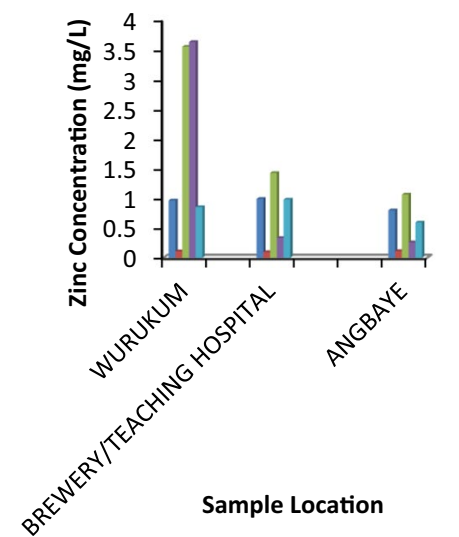

OCTOBER

NOVEMBER

DECEMBER

- JANUARY

MAY averages of $0.367 \pm 57.381,0.794 \pm 0.302,0 \pm 0.017,0.072$ \pm 0.031 and $0.217 \pm 0.012 \mathrm{mg} / \mathrm{L}$, respectively, during the wet spell. The presence of lead was quite high and found to be above the WHO, FAO and NSDWQ standards in the both seasons. Similarly, Cd was found to be above the recommended limits by WHO, FAO and NSDWQ in both periods. Conversely, the concentration of nickel was observed to fall below the WHO, FAO and NSDWQ limits in both seasons. Elevated levels of $\mathrm{Cd}$ and $\mathrm{Ni}$ can be injurious to human health (mainly by the high potency to contract gastro-intestinal ailments like diarrhoea and gastro-intestinal diseases) to man, domestic creatures and wildlife that utilize these aquatic resources for portable reasons (Ayenimo et al. 2010). Zinc and copper were found to be below recommended values of WHO and FAO but were above the NSDWQ in the dry season. Similar findings have been documented in the literature (Olatunji et al., 2012; Olubumi et al., 2010). These elements were however observed to be below all standards during the wet season (Figs. 3,4,5). The high levels of these metals in the
Table 3 Heavy metal index for River Benue

\begin{tabular}{llll}
\hline S/No & Heavy metals & \multicolumn{2}{l}{ Heavy metal index (HMI) } \\
\cline { 3 - 4 } & & Dry season & Wet season \\
\hline 1 & $\mathrm{~Pb}$ & 6080.00 & 7240.00 \\
2 & $\mathrm{Cd}$ & 8500.00 & 4900.00 \\
3 & $\mathrm{Ni}$ & $\mathrm{ND}$ & 2070.00 \\
4 & $\mathrm{Cu}$ & 13.40 & $\mathrm{ND}$ \\
5 & $\mathrm{Zn}$ & 35.50 & 47.07 \\
6 & Mean/overall & 7920.00 & 5088.56 \\
\hline
\end{tabular}

$N D$ : Not detected

dry season can be associated with leaching of industrybased effluents and clarification of water through nearby iron-containing land forms before moving into the river. Similar observations were posited by Akinbile et al. (2013), as well as Ayodele and Percy (2011) in their separate studies. 


\section{Heavy metal index and relative contributions}

The HMI and relative contributions from each heavy metal for the studied river in both seasons are as presented in Table 3. It was observed that the HMI ranged from 13.4 to 8500 in the dry season with a mean of 7920.2. The highest and lowest contributions were observed to emanate from $\mathrm{Cd}$ and $\mathrm{Zn}$, respectively. In the wet season, HMI varied from 47.07 to 7240 (mean $=5088.6)$. The highest contributions to the mean HMI in the wet season was observed to be as a result of the high concentration of $\mathrm{Pb}$, while the lowest contribution emanated from Zn pollution.

It was generally observed that the HMI values of River Benue for both the dry and wet spells were extremely above the threshold value (100) recommended for drinking water. These high values of HMI in the river can be attributed to diffuse and point source pollutions from agricultural and industrial activities on the river bank. The River Benue is the major sink for all pollution sources in the area, thus such high values of toxic pollutants in the river are expected as a result of expanding population and increased human/industrial activity with the Makurdi reach where the present study was conducted. These findings collaborate perfectly with the results shown for WQI, which proved that the River Benue water was of the type that could be classified as "Very Poor".

The HMI values reported for this study are expectedly found to be higher than those reported previously for groundwater (Zakhem and Hafez, 2015; Sharma et al., 2020). This was because surface water is expected to be more polluted as compared to groundwater as a result of contributions from both diffuse and point source pollutions to surface water bodies. Furthermore, high values of $\mathrm{Pb}$ and $\mathrm{Cd}$ in the river can be linked to the dumping of refuse in the vicinity of the river bank which is a constant practice in the area. Other possible sources of this metals include the effluents from a large meat processing units (abattoir) situated close to the bank of the river. The meat processors utilize waste tyres as source of energy for the roasting of slaughtered animals which deposit heavy metals into the effluents that are discharged directly to the river. Use of pesticides and fertilizers, effluents from a brewery and that from a teaching hospital all located close to the river may be the likely sources of heavy metal pollution.

\section{Principal component/factor analysis and pollutants' relationship}

Factor loadings for the dry spell are as shown in Table 4. From Table 4, it can be seen that three rotated factors were unravelled alongside the communality level during the dry
Table 4 Factor analysis for the dry spell

\begin{tabular}{lrrll}
\hline Parameters & Factor 1 & Factor 2 & Factor 3 & Communalities \\
\hline TDS & 0.135 & 0.189 & -0.256 & 0.789 \\
Electrical conduc- & 0.229 & 0.036 & -0.062 & 0.866 \\
$\quad$ tivity & & & & \\
Colour & -0.177 & 0.038 & 0.283 & 0.891 \\
TSS & 0.012 & -0.259 & -0.081 & 0.825 \\
PH & 0.176 & 0.191 & -0.016 & 0.563 \\
Temperature & -0.012 & 0.271 & 0.074 & 0.897 \\
Turbidity & 0.011 & 0.070 & 0.353 & 0.919 \\
Cadmium & 0.185 & -0.050 & 0.061 & 0.971 \\
Zinc & 0.055 & 0.303 & -0.049 & 0.967 \\
Lead & 0.151 & -0.039 & 0.166 & 0.984 \\
Copper & 0.088 & 0.044 & 0.259 & 0.764 \\
Nickel & -0.223 & -0.028 & 0.020 & 0.881 \\
\hline
\end{tabular}

Table 5 Factor analysis for the wet spell

\begin{tabular}{llrll}
\hline Parameters & Factor 1 & Factor 2 & Factor 3 & Communalities \\
\hline TDS & -0.486 & 0.034 & -0.024 & 0.238 \\
$\begin{array}{l}\text { Electrical conduc- } \\
\quad \text { tivity }\end{array}$ & 0.878 & 0.307 & -0.185 & 0.900 \\
Colour & & & & \\
TSS & -0.279 & 0.794 & 0.086 & 0.716 \\
PH & 0.480 & -0.116 & -0.235 & 0.300 \\
Temperature & 0.643 & 0.158 & 0.375 & 0.579 \\
Turbidity & 0.040 & 0.659 & -0.672 & 0.888 \\
Cadmium & 0.692 & 0.405 & 0.270 & 0.716 \\
Zinc & 0.181 & -0.570 & -0.563 & 0.675 \\
Lead & 0.653 & 0.211 & 0.250 & 0.533 \\
Copper & 0.855 & 0.033 & -0.214 & 0.777 \\
Nickel & 0.187 & -0.490 & 0.719 & 0.792 \\
\hline
\end{tabular}

period. Factor 1 was found to be positively laden with nine parameters TDS, EC, TSS, pH, turbidity, $\mathrm{Cd}, \mathrm{Pb}, \mathrm{Zn}$ and $\mathrm{Cu}$ as opposed to temperature, colour and $\mathrm{Ni}$ (negative stocking), which accounted for $32.3 \%$ of the rotated variance. $\mathrm{Cd}, \mathrm{Pb}, \mathrm{pH}$ and $\mathrm{EC}$ were found to have the highest positive loadings in factor one and could be said to be responsible for the pollution loads of the studied river water during the dry season.

Akinbile and Omoniyi (2018) also observed a negative loading of temperature in factor 1 in their studies on the Ogbese River, South-western Nigeria. Temperature, colour and nickel reduction are advantageous to the river pollution, however, lead, cadmium, zinc and turbidity were found to have the highest explainable communality in the pollution structure of the river. Conversely, factors two and three were observed to be positively loaded with 8 ( $\mathrm{Zn}$, temperature, $\mathrm{pH}$, TDS, colour, turbidity, $\mathrm{Cu}$ and $\mathrm{Zn}$ ) and 7 
(colour, turbidity, $\mathrm{Cu}, \mathrm{Pb}, \mathrm{Ni}, \mathrm{Cd}$ and temperature) parameters, respectively. Generally, $\mathrm{Cd}, \mathrm{Pb}, \mathrm{Zn}$ and turbidity had the highest extractable communalities and were termed as the main attributes for contamination of the river water in the dry spell. As stated earlier, the pollution of the river with heavy metals could be associated with various anthropogenic activities at the studied locations especially those involving industrial and commercial discharge, as well as indiscriminate dumping of unsegregated solid waste around the shores of the River Benue.

The contamination of Warri River as a result of indiscriminate industrial effluent releases has been reported by Ayenimo et al. (2005). According to the authors, the river was examined for metals like $\mathrm{Fe}, \mathrm{Cu}, \mathrm{Ba}, \mathrm{Pb}, \mathrm{Cd}, \mathrm{Cr}, \mathrm{Ni}$ and $\mathrm{Co}$. Findings revealed high levels of the metals at sampling locations that had close proximity to an industry. Relationship investigation of the metals also indicated mutual basis for the river pollution. Other water quality parameters also indicated raised levels in concentration, further signifying contamination of the river by the closely sited industry. A similar trend was also reported by Hatje et al., (2003) in their studies on trace metal dissolution in sediments of an estuary in Australia.

Table 5 shows three rotated factors and communalities for the wet spell, which revealed ten contaminants (TDS, EC, TSS, pH temperature, turbidity, cadmium, zinc, lead and copper) with the uppermost positive loadings in the first factor and accounting for $25.9 \%$ of the total rotated variance.
TDS, colour and Ni just as with the case in the dry season were negatively loaded in factor 1 during the wet season. This shows that they were likely not released from the same source with the pollutants that are positively loaded in factor1. Thus, the prevalence of $\mathrm{Pb}, \mathrm{Zn}, \mathrm{Cu}$ and $\mathrm{Cd}$ in River Benue water can be linked to a common source which is likely from waste disposed into the river, while Ni presence in the river may be as a result of seepage from industrial effluents or dissolution of basement rocks.

Research works done in several Nigerian cities had revealed that industry-based discharges are one of the foremost causes of surface water contamination in Nigeria (Ekiye and Luo, 2010). Industrial effluents when released untreated or partially treated into the rivers have potentials of aggregating water quality indices. Dada (1997) reported that "less than $10 \%$ of industries in Nigeria treat their effluents before being discharged into the rivers". This has globally paved way for high loadings of inorganic metals such as $\mathrm{Pb}, \mathrm{Cd}, \mathrm{Cr}$ and $\mathrm{Fe}$ in several aquatic entities (Wakawa et al., 2008).

Factors 2 and 3 were observed to be positively loaded with EC, colour, $\mathrm{pH}$, temperature, turbidity, $\mathrm{Zn}, \mathrm{Pb}, \mathrm{Ni}$, TDS and colour, $\mathrm{pH}$, turbidity, $\mathrm{Zn}, \mathrm{Cu}$ and $\mathrm{Ni}$, respectively, with $\mathrm{Pb}, \mathrm{Cu}, \mathrm{EC}$, temperature and $\mathrm{Ni}$ having the highest extractable communalities. This suggests that in the wet season, $\mathrm{Pb}$, $\mathrm{Cu}$ and $\mathrm{Ni}$ appear to be the main heavy metals responsible for the deteriorating quality of River Benue water. As earlier mentioned, $\mathrm{Pb}$ and $\mathrm{Cu}$ are likely released into the river as
Fig. 6 Dendrogram of hierarchical cluster analysis for all the stations in dry season

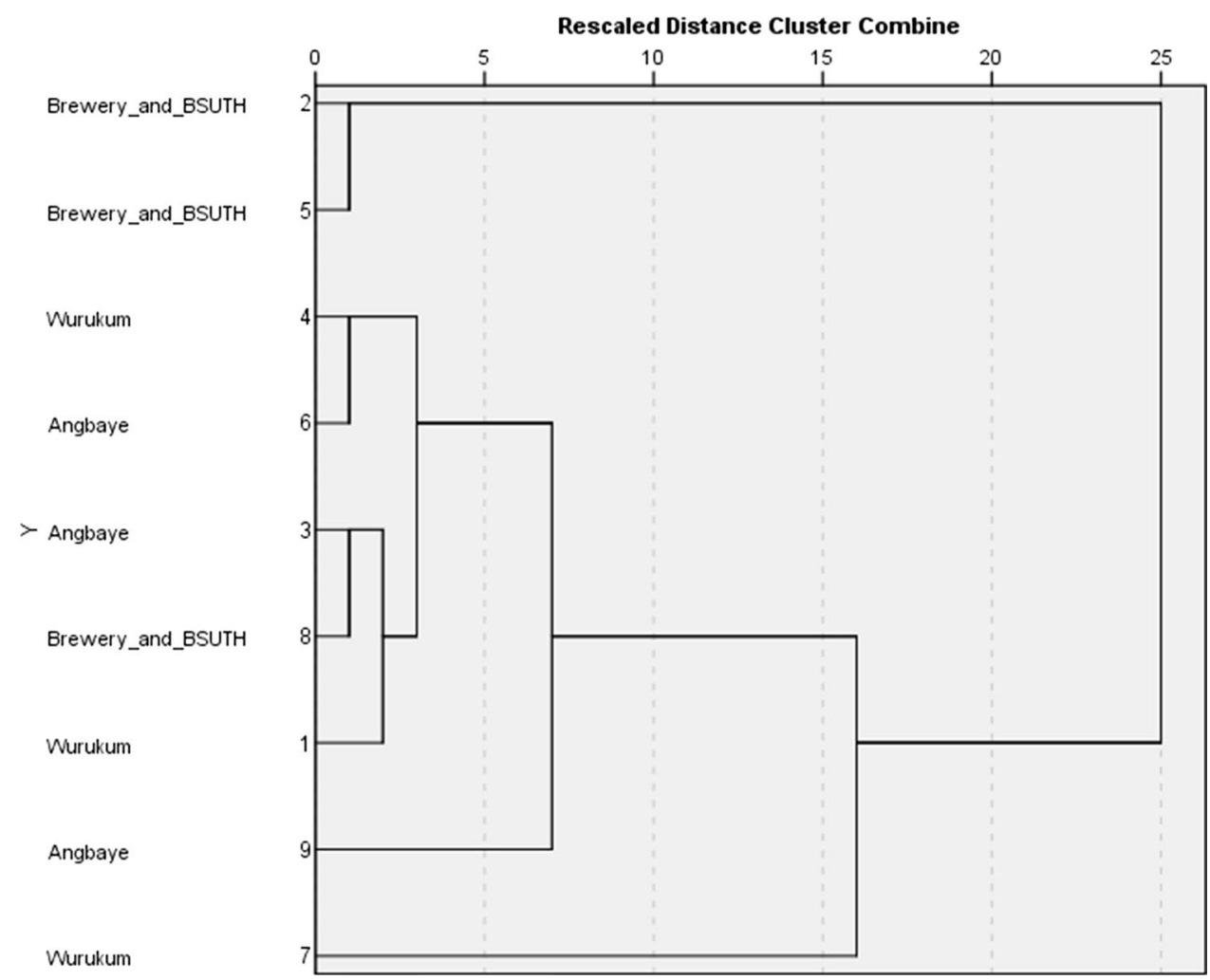


a result of anthropogenic influence, while Ni may be contributed from other sources including basement dissolutions (Wakawa et al., 2008; Ezomoh et al., 2019).

\section{Hierarchical cluster analysis and zoning of pollutions in the river}

Cluster analysis was accomplished using average values of the studied parameters for every sampling station both for the dry and wet spells. Figure 6 shows the results of four separated clusters along the river in the river shore during the dry season. From Fig. 6, it could be seen that the pollution levels of River Benue were in the order of cluster $4>1>3>2$. Clusters 2 and 3 were the least polluted stations and were of the same pollution levels. It can also be seen from Fig. 6 that clusters 2, 3 and 4 were associated to sampling point 1 (Angbaye), while clusters 1 and 3 were associated with sampling point 2 (Brewery and BSUTH) and clusters 2 and 4 were linked to sampling point 3 (Wurukum abattoir). Based on the foregoing, the River Benue water was zoned in terms of increasing pollution load in the order of Wurukum abattoir $>$ Brewery/BSUTH $>$ Angbaye. This trend was linkable to the numerous anthropogenic engagements at the Wurukum and brewery sampling point as compared to Angbaye which is just known for river bank agriculture and mild fishing and recreational activities. Several researchers have attributed an increase in river water pollution with increasing or diverse human activities (Akimbile and Omoniyi, 2018; Anyanwu et al., 2020; Oluyori et al., 2020).

Figure 7 again shows four (4) separated clusters for River Benue water during the wet season. Just as was observed during the dry season Fig. 6, the contamination ranks of River Benue during the wet season was in the order of cluster $4>2>3>1$. Clusters 1 and 3 were the least polluted and had similar pollution levels. It can also be seen from Fig. 6 that clusters 1 and 4 were associated with sampling point 1 (Angbaye), while cluster 3 was associated with sampling point 2 (Brewery and BSUTH). Cluster 2 was linked to sampling point 3 (Wurukum abattoir). Based on the foregoing, the River Benue water was zoned in terms of increasing pollution load for the wet season to be in the order of Angbaye > Brewery/

Table 6 Water quality index (WQI) classifications

\begin{tabular}{llll}
\hline BISWQI & OWQI & CCMEWQI & $\begin{array}{l}\text { Water } \\
\text { quality } \\
\text { category }\end{array}$ \\
\hline$\leq 50$ & $90-100$ & $95-100$ & Excellent \\
$50-100$ & $85-89$ & $80-94$ & Good \\
$100-200$ & $80-84$ & $65-79$ & Fair \\
$200-300$ & $60-79$ & $45-64$ & Poor \\
$\geq 300$ & $0-59$ & $0-44$ & Very Poor \\
\hline
\end{tabular}

Fig. 7 Dendrogram of hierarchical cluster analysis for all the stations in wet season

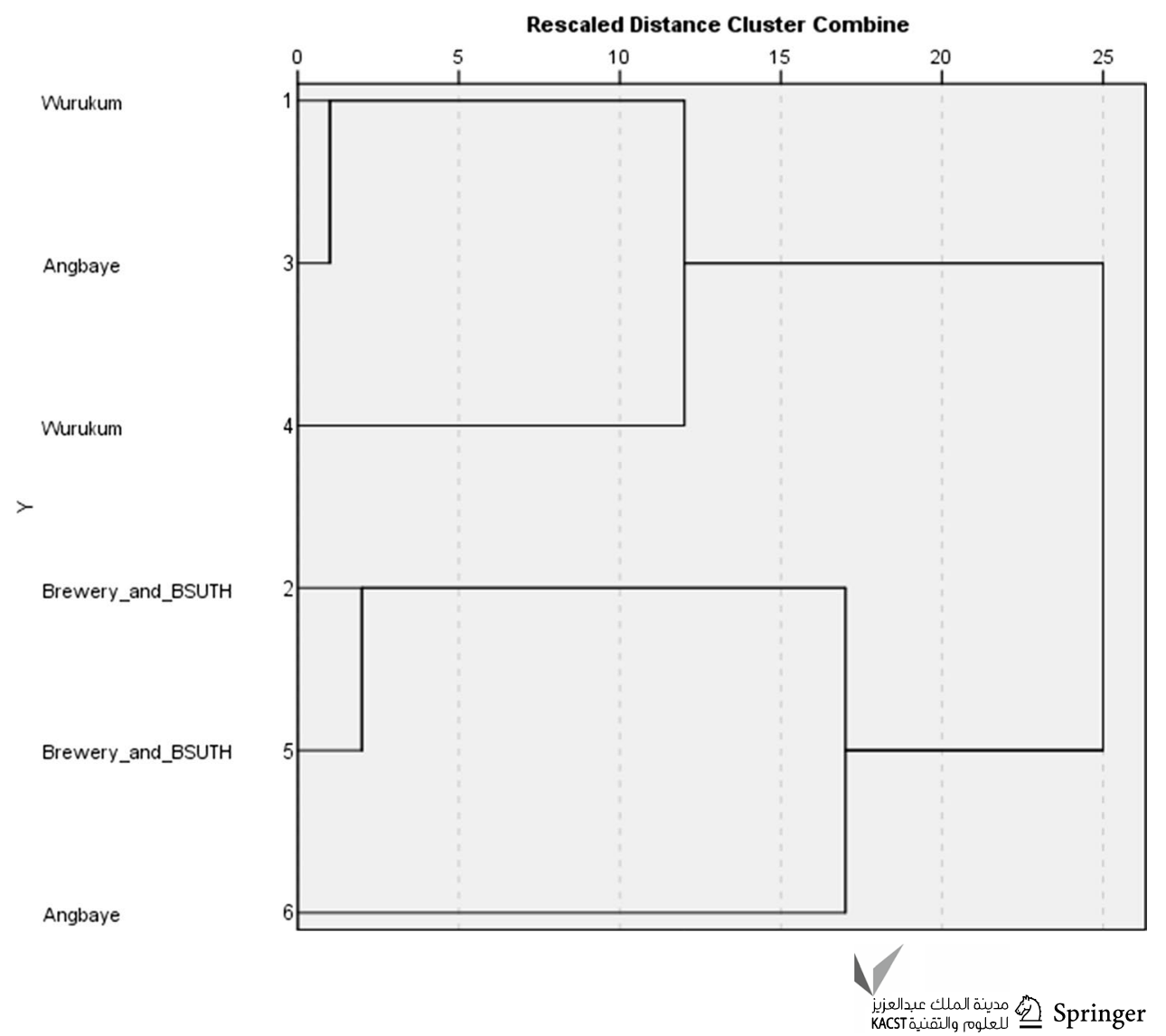


BSUTH $>$ Wurukum. This trend could majorly be attributed to the increased agricultural runoff entering the river at these sampling points, as well as intensive fishing activities especially in the month of October at these locations (Angbaye and Brewery/BSUTH). These findings are in tandem with those of (Hooda et al., 2000; Ayranci and Hooda, 2005; 2011; Talabi et al., 2020).

\section{Assessment of River Benue water using WQI}

The WQI of River Benue was estimated using three different indexes viz. the BISWQI, the OWQI and CCMEWQI using the appropriate water quality parameters. Results for the BISWQI during the dry spell were found to be 259.04 and those during the wet season were 236.51 which corresponded to the WQI classification class of "poor water" (Table 6). Similarly, results based on the OWQI gave values of 68.19 and 61.03 for the dry and wet seasons, respectively, which again corresponded to the classification as "poor water". Furthermore, estimates based on the CCMEWQI were found to be 53.11 and 46.63 for the dry and wet season, respectively, which again correspond to the classification as "poor water". Thus, it was found that all three WQI approaches adopted in the current study were suitable for estimating the WQI of River Benue. Kondom et al. (2021) made such observations in their study on the suitability of several water quality indexes for estimating River Benue water quality.

The foregoing suggest that potable and other industrial and commercial uses of water obtained from the River Benue at the studied location must be subjected to treatment before such uses as consuming it in its present form, both during the dry and wet seasons poses a great threat to human health and livelihood. Akimbile and Omoniyi (2018) reported similar values of 44.61 and 44.91 , based on the classification scale as reported by Elizabeth et al. (2010) and Pradyusa et al. (2009) for the quality of river Ogbese, respectively, for the dry and wet spells, which indicated that the water was bad and could be likened to the River Benue water at Makurdi as considered in the current study. This was another indication that Nigerian rivers are increasing in their pollution levels as a result of diverse factors including anthropogenic activities and urbanization. There is therefore an urgent need to promote continuous monitoring of surface water bodies in order to avert the inherent dangers associated with the consumption of heavily polluted water. Table 5 shows the WQI scale used in the current study.

\section{Conclusions and recommendations}

In this study, assessment of heavy metal pollution loads in River Benue water at Makurdi was carried out by employing the water quality index (WQI) and multivariate statistical tools. WQI based on the BIs standard was found to be $259.04 \%$ and $236.51 \%$, respectively, for the dry and wet spells and thus the water was classified as "poor water" in terms of its portable use potentials. The OWQI gave values of 68.19 and 61.03 for the dry and wet seasons, respectively, while the values obtained based on the CCMEWQI were 53.11 and 46.63 for the respective seasons. Comparatively, all WQI methods used revealed that the River Benue water could be classified as "poor water" and as such any of the approaches could reliably estimate the WQI of the studied river.

Factor analysis revealed three rotated factors. Factor one which revealed the highest level of pollution was positively loaded with TDS, electrical conductivity, TSS, pH, turbidity, cadmium, lead, zinc and copper as opposed to temperature, colour and nickel which were negatively loaded in factor 1. Lead, cadmium, zinc and turbidity had the highest communality in the dry season. On the other hand, factor 1 was positively loaded with TDS, electrical conductivity, TSS, $\mathrm{pH}$, temperature, turbidity, cadmium, zinc, lead and copper as opposed to colour and nickel in the wet season. Cluster analysis revealed that sampling points 3 (Wurukum Abattoir) and 2 (Brewery/BSUTH) were the most polluted in the dry season to the release of undiluted effluents into the river, while sampling point 1 was the most polluted during the wet season as a results of increased agricultural runoff into the river. It was experiential that the pollution levels of the water were associated more with increasing and diverse anthropogenic activities within and around the river course in the studied locations.

HMI analysis showed that cadmium and lead were responsible for the high mean HMI values (7920-5088) recorded for both the dry and wet seasons. This suggests that the River Benue water was grossly unfit for domestic and recreational uses.

Specifically, the study showed that there was an objectionable influence on the physico-chemical features of River Benue water, which can be attributed to nearby dumpsites that drain its leachates into the river, as well as from the activities of the Benue breweries, teaching hospital which discharges its untreated waste into the river and increased use of pesticides and fertilizers for agricultural production on the river banks which generate highly polluted runoff into the water body during the wet season.

The implications of the current findings is that domestic, recreational and agricultural consumption of River Benue water at the studied points without prior treatment might negatively disturb the health of man, water-based animals and plants in the vicinity of the polluted water. Apart from the above-mentioned findings, there is also a need to assess the health risk related with the portable consumption of 
untreated River Benue water at Makurdi by the residents in other to avert the suspected danger associated with the act.

\section{Limitations of the study}

Some limitations of the current include the following:

1. The River Benue water was not monitored throughout the year, only a few months were covered to span the two seasons. There could be some changes if the river was monitored throughout the year for 12 consecutive months.

2. Heavy metals in the samples were determined using the atomic adsorption spectrophotometer (AAS). More accuracies and sensitivity could be gotten if higher equipment like ICP-OES was used.

3. Not all standard water quality indexes were compared in the current study; there could be some discrepancies if other WQI methods are also considered.

4. HCA was used principally for zoning the rive course based on the monitored points into various pollution levels. Then, the land use practices and anthropogenic activities within the monitored points were used to infer the likely sources of pollution to the river especially with regards to heavy metals. HCA was not directly used to infer pollution sources and pollutant relationships as is with most study. Although this approach may look new, it also served to be a good method for inferring pollution sources to rivers.

Acknowledgements The authors wish to acknowledge the support received from the Environmental Chemistry Laboratory of the Benue State University, thank you for providing your laboratory space and instrumentation for this research work.

Author's Contribution J.T.U supervised the research and edited the manuscript. R.T.I and M.H participated in data collection, experimental designs and analysis, as well as writing the first draft of the manuscript.

Funding No funding was received for this research.

Data availability All data in this article are fully available without restriction.

\section{Declaration}

Conflict of interest The authors have declared that they have no conflict of interests regarding this paper.

Open Access This article is licensed under a Creative Commons Attribution 4.0 International License, which permits use, sharing, adaptation, distribution and reproduction in any medium or format, as long as you give appropriate credit to the original author(s) and the source, provide a link to the Creative Commons licence, and indicate if changes were made. The images or other third party material in this article are included in the article's Creative Commons licence, unless indicated otherwise in a credit line to the material. If material is not included in the article's Creative Commons licence and your intended use is not permitted by statutory regulation or exceeds the permitted use, you will need to obtain permission directly from the copyright holder. To view a copy of this licence, visit http://creativecommons.org/licenses/by/4.0/.

\section{References}

Akaahan TJA, Olabanji FM, Azua ET (2015) Studies on contamination of surface waters of river Benue with trace elements at Makurdi, Benue State, Nigeria. J Environm Chem Ecotoxicol 7(5):49-55

Akinbile CO, Omoniyi O (2018) Quality assessment and classification of Ogbese river using water quality index (WQI) tool. Sustain Water Resour Manag. https://doi.org/10.1007/s40899-018-0226-8

Akinbile CO, Yusuf MS, Talib SHA, Hassan ZA, Haque AMM, Samsudin UB (2013) Qualitative analysis and classification of surface water in Bukit Merah reservoir in Malaysia. Water Sci Technol 13(4):1138-1145

Al-Omran MA, El-Maghraby SE, Aly AA, Al-Wabel IM, Al-Asmari ZA, Nadeem ME (2015) Quality assessment of various bottled waters marketed in Saudi Arabia. Environ Monit Assess 185(8):6397-6406

Anwar K, Amir HM, Amir W, Shazmeen Z, Ghulam M (2011) Qualitative and quantitative analysis of drinking water samples of different localities in Abbttabad district-Pakistan. Inter J Phys Sci 6(33):7480-7489

Anyanwu ED, Umeham SN (2020) Identification of waterbody status in Nigeria using predictive index assessment tools: a case study of Eme River, Umuahia Nigeria. Int J Energy Water Resour 4(3):271-279. https://doi.org/10.1007/s42108-020-00066-5

APHA (2015) Standard methods for the examination of water and wastewater. American Public Health Association, Washington, USA

Asit KB, Surajit C (2015) Hydrogechemistry and water quality index in the assessment of ground water quality for drinking uses. Water Environ Res 87(7):607-617

Ayenimo JG, Yusuf AM, Adekunle AS, Makinde OW (2010) Heavy metal exposure from personal care products. Bull Environ Contam Toxicol 84(1):8-14

Ayodele RI, Percy CO (2011) Pollution effect of food and beverages effluents on the Alaro River in Ibadan City. Nigeria Chem Soci Ethiopia 25(3):347-360

Ayranci E, Hooda N (2005) Adsorption kinetics and isotherms of pesticides into activated carbon-cloth. Chemosphere 60:1600-1607

Briace J, De-Ferrati D (2008) Water for Rural Communities: Helping people help themselves. The World Bank Washington, DC USA, pp 1-8

Călmuc A, Călmuc M, Ţopa MC, Timofti M, Iticescu C, Georgescu LP (2018) Various methods for calculating the water quality index. Ann UGAL Math Phys Mec 41(1):171-178

Charkhabi AH, Sakizadeh M (2006) Assessment of spatial variation of water quality parameters in the most polluted branch of the Anzali wetland Northern Iran. Polish J Environ Studies 15(6):395-403

Chikogu V, Adamu IC, Vivan EL (2012) Public health effects of effluent discharge of kaduna refinery into river Romi. Greener J Medical Sci 2(3):064-069

CPC Board CPCB, 2007 Guidelines for water quality monitoring Parivesh Bhawan East Arjun Nagar, Delhi, India 3135

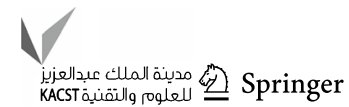


Dada, O (1997). Water quality: monitoring and assessment: https:// books.google.com.ng

Ejembi E, Terver S, Jonathan U (2018) Assessment of heavy metals concentration in shore sediments from the bank of River Benue, North Central Nigeria. J Geosci Environ Protect 6:35-46

Ekiye E, Luo Z (2010) Water quality mornitoring in Nigeria case study of Nigeria's industrial cities. J Am Sci 6(4):24-28

Elizabeta CA, Michael GH, Andrzej K, Paul SA (2010) Assessment of pollutant transport and river water quality using mathematical models. Acad Romana 55(4):285-291

Eneji IS, Sha'Ato, R. and Annune, P.A. (2011) An assessment of heavy metal loading in river benue in makurdi metropolitan area north central Nigeria. Environ Monit Assess 187(1):201-207. https:// doi.org/10.1007/s10661-011-1959-0

Eneji IS, Onuwa PO, Oloruntoba SO (2017) Post flood analysis of heavy metals level in river benue along Makurdi Metropolis, Nigeria. Acad J Chem, Acad Res Publ Group 2(8):74-79

Ezomoh OO, Azikiwe S, Sunday BE, Okemmadu AC (2019) Determination of heavy metal, cadmium, iron, lead, mercury, tin, nickel and vanadium in four different water samples in bayelsa metropolis. J Researc Environ Earth Sci 5(1):16-19

FAO (Food and Agriculture Organization) (2015). United Nations, CODEX STAN

Fatai E (2011) Assessment of surface water quality using principle component analysis and factor analysis. World J Fish Marine Sci 3(2):159-166

FFTC (Food and Fertilizer Technology Center), (2008). Monitoring and management of agricultural water quality for green food production. Annual report of FFCT Wenchow st Taiwan. Pp 7-112.

Hamed HK (2012) Qualitative assessment and classification of Aji Chai River using water quality index (WQI). World J Fish Marine Sci 4(1):50-53

Hatje V, Apte SC, Hales LT, Birch GF (2003) Dissolved trace metal distributions in port jackson estuary (sydney harbour) Australia. Marine Pollut Bull 46(6):719-730

Hooda PS, Edwards UC, Anderson HA, Miller A (2000) A review of water quality concerns in livestock farming areas. Sci Total Environ 250:143-167

Igbinosa EO, Uyi OO, Odjadjare EE, Ajuzie CU, Orhue PO, Adewole EM (2012) Assessment of physico-chemical qualities, heavy metals concentrations and bacterial pathogens in Shanomi Creek in the Niger Delta Nigeria. African J Environ Sci Technol 6(11):419-424

Isikwue MO, Oyilo AF (2010) Influence of land use on the hydraulic response of loamy sand tropical soil. J Eng Appl Sci 1(2):145-150

Jaji MO, Bamgbose O, Odukoya OO, Arowolo TA (2007) Water quality assessment of Ogun river, South West Nigeria. Environ Monit Assess 133(3):473-482

Ketata-Rokbani M, Gueddari M, Bouhlila R (2011) Use of geographical information system and water quality index to assess groundwater quality in El Khairat deep aquifer (Enfidha, Tunisian Sahel) Iran. J Energy Environ 2(2):133-144

Kondum FA, Iwar RT, Kon ET (2021) A Comparison of water quality indexes for an inland river. J Eng Res Reports 20(4):1-14

Li Y, Hong YT, Wang DJ, Zhu YX (2007) Determination of Free heavy metals ion concentrations in soil around a cadmium rich zinc deposit. Geochem J 41:235-240

Monbreshora C, Osibanjor O, Ajayi SO (1983) Pollution studies on Nigerian Rivers: the onset of Lead pollution of surface waters in Ibadan. Environ Int 90(2):81-84. https://doi.org/10.1016/01604120(83)90057-0

NBS (National Bureau of Statistics), (2009). Data census Bulletin.

NIMET (Nigerian Meteorological Agency), (2009). Climate review bulletin, pp 1-33.

NSDWQ (Nigeria Standard for Drinking Water Quality) (2015) Nigeria Industrial Standard. NIS 554:13-14
Ogedengbe K, Akimbile CO (2004) Impact of industrial pollutants on quality of ground and surface waters at oluyole industrial Estate Ibadan Nigeria. J Tech 31(2):33-45

Ogendegbe K, Akinbile CO (2010) Comparative analysis of the impact of industrial and agricultural effluent on Ona stream in Ibadan Nigeria. J Sci Technol 31(2):33-45

Olatunji OS, Osibanjo O (2012) Determination of selected heavy metals in inland fresh water of lower River Niger drainage in North Central Nigeria. Afr J Environ Sci Technol 6(10):403-408

Olubumi FE, Olorunsola OE (2010) Evaluation of the status of heavy metals of sediment of agbabu bitumen deposit area Nigeria. Eur J Sci Res 41(3):373-382

Oluyori NR, Alhassan MM (2020) Assessment of urban storm runoff water quality in lugbe abuja municipal area council FCT Nigeria. J Res Wildl Environ 12(1):138-147

Orobator PO, Akiri-Obaroakpo TM, Orowa R (2020) Water quality evaluation from selected aquaculture ponds in Benin City, Nigeria. J Res Wildl Environ 12(1):24-33

Park M, Reckhow D, Lavine M, Rosenfeldt E, Stanford B, Park M (2014) Multivariate analysis for monitoring EDCs and PPCPs in a Lake. Water Environ Res 86(11):2233-2241

Pradyusa S, Basanta KM, Chitta RP, Swoyan RP (2009) Assessment of water quality index in mahanadi and atharabanki rivers and taldanda canal in paradip area India. J Human Ecol 26(3):153-161

Radojevic, M. and Bashkin, V.N. (1999). Practical Environmental Analysis. Royal Society of Chemistry Cambridge. 886pp.

Ramakrishnalah CR, Sadas Hivalah C, Ranganna G (2009) Assessment of water quality index for the groundwater in Tumkur Taluk, Karnataka state India. E-J Chem 6(2):523-530

Raman BV, Reinier B, Mohan S (2009) Fuzzy logic water quality index and importance of water quality parameters. Air Soil Water Res 2(1):51-59

Rana R, Ganguly R, Gupta AK (2018) Indexing method for assessment of pollution potential of leachate from non-engineered landfill sites and its effect on ground water quality. Environ Monit Assess 190:46. https://doi.org/10.1007/s10661-017-6417-1

Sharma S (1996) Applied multivariate techniques. Wiley, New York, pp 144-181

Sharma A, Ganguly R, Gupta AK (2020) Impact assessment of leachate pollution potential on groundwater: an Indexing method. J Environ Eng 146(3):05019007. https://doi.org/10.1061/(ASCE) EE.1943-7870.0001647

Talabi AT, Odunaike KO, Akinyemi LP, Bashiru BO (2020) Investigation for heavy metals in river waters in the federal capital territory North Central of Nigeria. Int J Energy Water Res (In Press). https://doi.org/10.1007/s42108-020-00063-8

"The World Gazetteer". Archived from the original on 9 February 2013. Retrieved 6 April 2020.

Ubwa SA (2013) Levels of some heavy metals contamination of treat dust in the Industrial and high traffic density area of Jos metropolis. J Biodivers Environ Sci 3:13-21

Vasistha P, Ganguly R (2020) Assessment of spatio-temporal variations in lake water body using indexing method. Environ Earth Sci 73:6591-6600. https://doi.org/10.1007/s11356-020-10109-3

Wakawa AM, Saidu L, Abdu PA, Joannis TM (2008) Impact assessment of effluent discharge on physiochemical parameters and some heavy metal concentrations in surface water of River Callawa, Kano - Nigeria. Afr J Pure Appl Chem 2(10):100-106

WHO (World Health Organization, (2010). International standard for drinking water. 3rd Edition.

WHO (World Health Organization) (2015). Guideline for drinking water quality, 2nd Edition, Vol 2.

Yilmaz I (2007) Fuzzy evaluation of water quality classification. Ecol Ind 7(3):710-718 
Zakhem BA, Hafez R (2015) Heavy metal pollution index for groundwater quality assessment in Damascus Oasis Syria. Environ Earth Sci 73:6591-6600. https://doi.org/10.1007/s12665-014-3882-5
Publisher's Note Springer Nature remains neutral with regard to jurisdictional claims in published maps and institutional affiliations. 